\title{
Limits of Criminal Legitimacy in Use of Reproduced Works
}

\author{
Saleem Isaaf Alazab ${ }^{1}$, Sabah Mousa Almomani ${ }^{1}$ \& Atef Salem Alawamleh ${ }^{1}$ \\ ${ }^{1}$ College of Law, Balqa Applied University, Al-Salt city, Jordan \\ Correspondence: Saleem Isaaf Alazab, College of Law, Balqa Applied University, Al-Salt city, Jordan. E-mail: \\ dr.saleem-alazab@bau.edu.jo
}

Received: August 18, 2019

Accepted: September 18, 2019 Online Published: November 28, 2019

doi:10.5539/jpl.v12n4p64

URL: https://doi.org/10.5539/jpl.v12n4p64

\begin{abstract}
The use of a reproduced work is a criminally legal act if it is used by a reproducer of such work within a specific group of individuals. However, the use of the same reproduction is criminally prohibited if it is used collectively, and if it violates the normal exploitation of the original work or harms authors' legitimate interest. Thus, the protection of interest of the authors requires that reproduction of some works is prohibited, in whole or in part, for the private use under some certain controls.
\end{abstract}

Keywords: french intellectual property code-criminal law

\section{Introduction}

Reproduction of others copyrighted works ${ }^{1}$ falls within limits of criminal legitimacy, and does not constitute an offense of imitation of intellectual works if a reproducer of the copyrighted works complies with reproduction controls, i.e. the purpose of reproduction is the private use of the reproduced work. In this case, a reproducer is not required to seek permission ${ }^{2}$ of an author for reproduction of his works. Since the criminal legislator in the modern era is required to be precise and clear in criminalization and penalization, by establishing clear limits between permitted and prohibited acts, definition of private use of a reproduction and differentiation of it from the collective use is the problem of this study (2). Though reproduction of all intellectual works is permitted, the French legislator does not permit such reproduction if it breaches normal exploitation of work or harms legitimate interest of the author, which requires defining the works to which exclusion of the copy assigned for the public applies and the works that are not assigned for the public under specific controls. This definition is the other part of the problem of this study (3). Hence, it has been decided that conducting an analytical study on the French Intellectual Property Code is the best approach to identify the juristic opinions and case law on the problems raised by this study, in order to address shortcomings in its subject.

\section{Theoretical Background}

\subsection{Private Use as a Purpose for Reproduction of Works}

In accordance with Article (L.122-5-2) of the French Intellectual Property Code which provides that "Once a work has been disclosed, the author may not prohibit: 2. copies or reproductions reserved strictly for the private use of the copier and not intended for collective use",3, a reproducer who benefits from the private copy exception is the person who privately uses the copy.

The said Article arises two questions that should be answered in two requirements:

- $\quad$ Who does have the right to use the copy ?(1-2).

\footnotetext{
${ }^{1}$ According to the glossary of copyright terms, reproduction of works means preparation of one reproduction or more of a work or any important portion thereof in any material form including audio or visual recording. See glossary of copyright and neighboring rights terms, World Intellectual Property Organization (WIPO), 1981, term No. 223.

${ }^{2}$ The exclusive right exercised by an author as to his works contradicts the public interest of society in benefiting from such works by members of society, where production of such works is basically based on the cultural wealth of society which has been formed in cumulative way based on creative works of former authors.

${ }^{3}$ Article (L.122-5-2) of the French IP Code provides that: Lorsqe loeuvre a été divulguée, l'auteur ne peut interdire: $2^{\circ}$ Les copies ou reproduction strictement reserves à l'usage privé du copiste et non distinées à une utilization collective, à l'exception des copies des oeuvres d'art destinées à être utilisées pour des fins identiques à celles pour lesquelles l'exception des fins identiques à celles pour lesquells l'ouvre originale a été crée (L.n ${ }^{\circ}$ 94-361 du 10 mai 1994) et les copie dun logiciel autres que la copie de sauvegsrde etablie dans les conditions au II

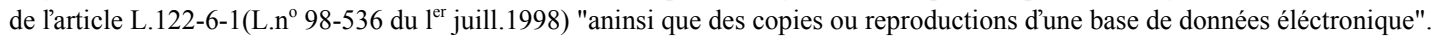


- What does "private use" mean ?(2-2)

\subsection{The Person Who Has the Right to Use the Work}

Legality or illegality of use of copy of the work is determined according to the person who uses the reproduced work. If a user of the work is the author and such author makes it available to others, this act is undoubtedly criminally legal, since the exclusive right exercised by the author as to his work allows him to permit any person to reproduce his works. However, if the work is reproduced by a person other than the author, use of the work can occur in two cases:

Case1: if the reproducer uses the work privately without sharing it with others, there is no imitation offense, where the legislator permits the public to do so as an exception from the exclusive right of the author to his work.

Case 2: if a reproducer of a work makes it available to others without permission of the author, this act is criminally illegal since the use is intended for two persons, not for own use of the reproducer, which is not a private use, rather it is sort of the collective use which contradicts the private use of the copyrighted works. ${ }^{4}$

In this context, we, along with some jurists, ${ }^{5}$ believe that there is no reason to argue that the electronic work is not simultaneously available for all users of the Internet, or that the public connected to the work is distributed in several places, as long as the public can obtain a copy of it. Hence, Pontoise Court charged an accused with the imitation of works offense on the ground that he downloaded about 10 thousand music works from other computers connected to one net and made them available to users of the internet, rejecting his defense that he benefited from the exception of the private use for the reproduced work. ${ }^{6}$ We support the jurists ${ }^{7}$ who argue that the website that publishes works is open for the public and can be accessed without a password, where reproduction is legal whether the purpose of use of a work is private or collective. Yet, if a website cannot be accessed without a password, then reproduction for a private use should be guaranteed. Hence, the concept "private use" should be defined as a purpose for permissibility of reproduction of works unprotected under the law, so that the one who benefits from the private copy exception is within the limits of criminal legitimacy and is not charged with the offense of intellectual works imitation.

\subsection{Concept of Private Use}

Some jurists argue that the private use of a copy of work is not intended to give a narrow meaning in which use of a reproduced work is confined exclusively to the personal interest of a reproducer, like research or a study, rather it includes use of a work by a certain group of people who have close relationships with a reproducer, like family relationships or friendships ${ }^{8}$.Otherwise, practical problems will arise, the less serious of which is lack of control over reproduction of works in use of them in the scope of the private relationships. Hence, we believe that the offense of imitation is not established if a copy of work is used within the family, where such use remains within sphere of privacy, even if it is not personal in the narrow sense. In support of this, Paris Court of Appeal decided that "the necessary permission of owner of a CD to make a copy of it is not exclusively for use

\footnotetext{
${ }^{4}$ Dr. Mohammad Abd Al-Fattah Ammar, Restrictions on the Financial Right of the Author, Dar Jamia Jadida, Alexandria, 2015, p.264-265.

${ }^{5}$ Abd Al-Hadi Fawzi Awadi, Legal System of the Private Copy of Copyrighted Works, Dar Nahda Arabia, Cairo, 2007, p.135.

${ }^{6}$ The judicial decision says " Lélément materiel resort du telechargement d,environ 10000 oeuvres musicales provenat d,autres ordinateurs connectés..et la miseé disposition des internautes, il s,agit d,un acte de reproduction, chaque fichier d’une oeuvre numeriséeétant copié pour etre stocké sur le disque dur de 1,interanaute qui le recetionne et d'un acte de representation consistent dans la communicatin de l'oceuvre au public des internautes...dans le réseau de peer to peer utilisé par Monsieur o., celui-ci accomplit les deux operations..." T.G.I Pontoise 2 février 2005:D.2005,no 21,p1436,note Legros".

${ }^{7}$ Bin Omar Yasin, Ground of Permissibility in Crimes of Imitation of Literary and Artistic Works in the Algerian Legislation, Journal of Jurisprudence and Law, Algeria, $6^{\text {th }}$ issue, April 2013, p.118.

${ }^{8}$ Hawas Fathia, the Private Copy as a Restriction on the Financial Right of the Author, Journal of Law and Political Science, Université Abbès Laghrour Khenchela, issue 8, June 2017, $2^{\text {nd }}$ Part, p.619. Dr. Osama Ahmad Bader, Circulation of Works Online (problems and solutions in light of Law No. 82 of 2002 on Protection of Intellectual Property Rights, Dar Jama Jadida, Alexandria, 2004, p.85.Abd Al-Hafith Belqadi, Concept of Copyright and Limits of its Criminal Protection, $1^{\text {st }}$ edition, Dar Aman, Rabat, 1997, p.329. Dr. Mohammad Abd AL-Fattah Ammar, ibid, p.227. Dr. Nawwaf Kanan, Copyright (Modern Models of Copyright and its Protection Methods), $3^{\text {rd }}$ edition, Dar Thaqafa Library, Amman, 2000, p.239. Dr. Ashraf Jaber Said, Towards Modern Concept of the Private Copy ( a comparative study in concept of a private copy as a restriction on the exclusive rights of the author and owners of neighboring rights between digital reproduction means and measures of technological protection) Dar Nahda Arabia, Cairo, 2007, p.82. Dr. Abd AL-Hadi Fawzi Awadi, ibid, pp.89 and 90. Bin Omar Yasin, ibid, p.114.Ziad Tareq Jasem Al Binyan Rawi, Uncopyrighted Works assigned for Personal Use, an Article 30.05.2016, published online: http://almerja.com/reading.php?idm=49126
} 
of a reproducer, rather it can extend to include the use within family"9.

However, other jurists argue ${ }^{10}$ that requiring absolute exclusion of collective use arises practical difficulties concerning some forms of use that may be deemed to be private use, such as the professional use, as the case of a researcher who collects the scientific material to perform his personal action, and a lawyer who collects intellectual works, like books and articles, to do his job. We believe that such use is within limits of the private use. Nevertheless, the matter differs when it comes to the internal use, which is deemed to be a collective use, where the copy is used inside a certain firm or enterprise beyond limits of use of the reproduced work. This use is criminally illegal since the copy is collectively (no privately) used, and this was the judgment "when an institution made a copy of the economic supplement of Le Figaro newspaper to use it in a report on its annual activity. In its decision, the court relied on the assumption that such use was internal inside the institution, but the purpose of reproduction was the collective sue of the report, as evidenced by presenting the report to the shareholders and financial analysts in that institution". ${ }^{11}$

In all cases, illegality of reproduction and thus commission of the imitation offense are established if works are made available to a person other than the reproducer whether such action is made for money or for free ${ }^{12}$. This was ruled by Chateausx Court which fined an accused of imitation five hundred Euro for reproduction of audio and visual works and made part of them available to the public for money, and made other part for free. ${ }^{13}$

\section{Works Excluded from the Scope of Use of the Private Copy}

If use of all reproduced intellectual works, whether traditional or digital, is in principle permitted in a private manner, Article (L.122-5) of the French Intellectual Property Code provides for illegality of copy of the work if such copy violates normal use of the work or causes damage to the author (3.1). Since damage to interest of the author is inevitable, the legislator prohibits reproduction of some works and permits reproduction of certain works under certain controls (3-2).

\subsection{The Works Excluded for Their Conflict with the Interests of the Author}

Article (L.122.5) provides that "the exceptions set out in this Article shall not prejudice the normal exploitation of a work nor shall they unjustifiably harm legal interest of the author" ${ }^{\prime 14}$, where the author cannot object to reproduction of his work for the private use purposes unless the damage caused to his interest is unjustified. This takes place if reproduction of the author's work causes serious damage. We believe that this control is an appropriate tool to strike balance between the public's benefit from private reproduction of works exception and interest of the author who is required to prove that use of such exception by others has resulted in violating the normal exploitation of his work and harming his interest. In order to achieve this objective, a judge may resort to some controls to estimate whether the damage exists or does not. This includes the purpose of use of the reproduced work, where damage to the author's legitimate interests is unjustifiable if the purpose beyond use of the copy is achievement of commercial objectives, including significance of the reproduced part to the whole original work. In looking into legality of use of the reproduced work, the trial judge establishes the presumption of illegality of reproduction if size of the reproduced part is significant. On the contrary, presumption of criminal illegality does not exist if reproduction constitutes only a small or insignificant part of the whole work. Moreover, impact of use of the reproduced work on the marketing of the original work should be considered, where the work is criminally illegal used if the copy of work competes the economic means through which the author utilizes his work. The author is required to prove, under economic evidence, that there is breach of the normal exploitation of the work which has a diverse effect on marketing of the original work. In light of this, the French Court of Cassation ruled that "breach of normal exploitation of work that renders exception of private use of a reproduced work inapplicable should be estimated according to risks of the new electronic environment as to

\footnotetext{
${ }^{9}$ The decision says: "L'usage privé ne saurait être réduit à in usage strictement slitaire, de sorte qu'il doit bénéficier au cercle de proches, entendu come un Groupe restraint de personnes qui not ente elles des liens de familles ou d'amitié". Cour d'appel Paris, 4 avril 2007, M.Stéphane (P), UFCQUE-Choisir c/UNIVERSAL Pictures Video FR, SEV, Films Alain Sarde, Studio canal : Juriscom. net,http://www.juriscom.net/jpt/visu.php?ID=685"

${ }^{10}$ Dr. Ashraf Jaber Said, ibid, p.87. Dr. Mohammad Abd Al-Fattah Ammar, ibid, p.235.

11 paris, $1^{\text {er }}$ October 1990, RIDA, Juillet 1991, p 206, obs A keever

12 Dr. Ramzi Abid AL-Rahman Sheikh, Neigbouring Rights of Copyright, Dar Jama Jadida for Publication, Alexandria, 2005, p.234, and Dr. Hawas Fathia, ibid, p.615

${ }^{13}$ He referred to this ruling:Dr. Fathia Qourari, The Criminal Confrontation of Cyber-Piracy of Electronic Works by Peet to Peer, Journal of Law-Kuwait University, Issue 1 (34) March 2010, p. 303.

${ }^{14}$ The decision says:"Les exceptions énumerées par le present article ne peuvent porter atteinte a l'exploitation normale de l'oeuvre ni causer un prejudice injustifié aux interest légitimes de l'auteur".
} 
preservation of copyright and the economic significance of the exploitation of the work on DVD for covering cost of cinematographic production". ${ }^{15}$

\subsection{Works Included for Their Nature or Cost}

The French legislator prohibits reproduction of some works, like artistic works which are made for the same purposes for which the original work is prepared (3-2-1). Some works are excluded from the scope of exception of private use of reproduced work due to the high cost incurred by authors in producing them, such as reproduction of computer software, except for reservation purposes, as well as for the reproduction of essential parts of the database works (3-2-2).

\subsubsection{Works Excluded for Their Nature (Artistic Works)}

Privacy of innovation in the artistic works domain requires a limited number of copies of such works; where this reproduction would impede the normal exploitation of the artistic work and harm the interests of their authors. Hence, reproduction of artistic works that are used for the same purposes of original work is criminally illegal if a painting, for example, is placed in a public gallery, since such behavior falls within the collective use of the reproduced work, and the author's consent must therefore be obtained for the authorization of the reproduction. On the contrary, reproduction of the work is criminally legal if it is made for educational purposes like explanation, illustration and scientific research, so that permission of the author for such reproduction is not required. ${ }^{16}$

\subsubsection{Works Excluded for Their Cost}

Given damage to the author caused by reproduction of the electronic works due to the large sums spent on making such works, the French legislator permits reproduction of these works only as an exception under certain controls, as follows:

\subsubsection{Computer Software}

The legislator excludes computer software from the scope of the private copy exception, where reproduction of such software is subject to permission of its author. In other words, a copy is criminally illegal without such permission. In Article (L.122-6/1), the legislator however permits making a copy of software called (backup copy). We argue that such copy is not a private copy since controls of its legal use differ from the controls of legal reproduction of a work for private use. The most important differences include:

a. Purpose- the private copy is used for research and study purposes, while the backup copy is used as replacement of the original work if it is lost or damaged, where use of the copy for another purpose, like reproduction of software for commercial purposes, for example, is an illegal act and is deemed to be a criminally punishable imitation. ${ }^{17}$

b. Scope of use- every person of the public can obtain a copy of work for the private use without permission of the author, as to all works not excluded by the legislator from the scope of private copy of works, while the backup copy is provided by the original software provider to the client in anticipation of damage or loss of the original copy. ${ }^{18}$

c. Future of the copy- keeping the only backup copy is linked to the continued legitimate possession of the original copy of the software. If the period for use of the original copy expires, the period for keeping the backup copy expires and thus it should be destroyed. ${ }^{19}$

\footnotetext{
${ }^{15}$ The decision says: "Latteinte à l'exploitation normale de l'oeuvre, proper à faire écarter l'exception de copie privées'apprécie au regard des risques inhérents au au nouvel environnement numérique quant à la sauvegarde des droits d’auteur et de limportance économique que l'exploitatation de l'oeuvr, sous forme DVD, représente pour l'amortissement des couts de production cinématographique". Arrét no 549 du 28 février 2006, Cour de cassation-Premiére chambre civile".

${ }^{16}$ Dr. Ashraf Jaber Said, ibid, p.48 and beyond. Dr. Mohammad Abd AL-Fattah Ammar, ibid, pp.186, 187.

${ }^{17}$ Dr. Khaled Mustafa Fahmi, Legal Protection of Computer Software in Light of Intellectual Property Protection law, Dar Jama Jadida, Alexandria, 2005, p.160. Ali Ahmad Farjani, Criminal Protection against Imitation Computer Software and its Distribution, and the Violations related to Use of Internet in Various Activities, Law and Economic Journal, Faculty of Law, Zagazig Universit, issue 17, 2005, p.112.

${ }^{18}$ Dr. Ashraf Jaber Said, ibid, p.58.

${ }^{19}$ Dr. Saad Said Masri, Legal System of Information Programs as an Intellectual Property Application, ( a comparative study) Dar Nahda Arabia, Cairo, 2015. Dr. Shehata Gharib Mohammad Shalqami, Moral Right of Author of Computer Software (a study on the new Intellectual Property Protection Law No. 82 of 2002), Dar Jama Jadida, Alexandria, 2008, p.31.
} 


\subsubsection{Databases $^{20}$}

The legislator prohibits reproduction of the whole or any significant part of the database by electronic means of private use. However, he permits reproduction of an insignificant part of database. However, the frequent and regular reproduction of insignificant parts will render such parts significant when accumulated, which contradicts intention of the legislator as to the database works. ${ }^{21}$

\section{Conclusion}

Reproduction of others' works is an exception that should not be expanded so as not to be detrimental to the interests of the author, where the purpose of reproduction should be the private use by the reproducer. In this case, permission of the author for reproduction of his works is not required.

Legality or illegality of use of copy of the work is determined according to the person who uses the reproduced work. If a user of the work is the author and he makes it available to others, this act is undoubtedly legal, since the exclusive right exercised by the author allows him to permit any person to reproduce his works. However, if the reproducer uses the work privately without sharing it with others, then this act is criminal legal in this case, where the legislator permits the public to do so as an exception from the exclusive right of the author. On the other hand, if a reproducer of a work makes it available to others without permission of the author, this act is criminally illegal since the use is intended for two persons, not for own use of the reproducer, which is not a private use, rather it is sort of the collective use which contradicts the private use of works of others.

The use concluded by this study is broader than the personal use, where it includes use of the copy in a special circle of people, such as family relationships and close friendships. The use is deemed to be private if it is for educational or professional purposes- other than commercial purposes- save the internal use which is collective. This agrees with the practical reality in use of reproduced works.

Illegal use of a reproduced work describes a copy of work whose use causes serious damage to the author's interests who is required to prove that use of exception by others has resulted in violating the normal exploitation of his work and harming his interest. In this context, the trial judge may estimate existence or non-existence of the harm using certain controls, like the purpose beyond reproduction of a work- educational or commercialnature of a work, size of the reproduced part and its significance compared with the original work, and impact of use of a reproduced work on marketing of the original work.

Though all intellectual works are, in principle, is subject to the private copy exception of whatsoever nature, privacy of innovation in the artistic works domain requires that reproduction of such works is criminally illegal if it is used for the same purposes for which the original work has been created.

Furthermore, some works are excluded from the scope of private use of a reproduced work due to the high cost incurred by authors in making it such as computer software whose reproduction is completely prohibited save making a backup copy of the software under special conditions that differ from the conditions on benefiting from the private copy of works.

Reproduction of the whole or any significant part of database is prohibited. Frequent and regular reproduction of insignificant parts of database is also prohibited and the trial judge has the power to decide legality or illegality of the criminal act.

\section{References}

Ammar, M, A. (2015). Restrictions on the Financial Right of the Author. Dar Jamia Jadida, Alexandria.

Awadi, A. F. (2007). Legal System of the Private Copy of Copyrighted Works. Dar Nahda Arabia, Cairo.

Bader, O. A. (2004). Circulation of Works Online (problems and solutions in light of Law No. 82 of 2002 on Protection of Intellectual Property Rights). Dar Jama Jadida, Alexandria.

Belqadi, A. A. (1997). Concept of Copyright and Limits of its Criminal Protection (1st ed.). Dar Aman, Rabat.

Fahmi, K. M. (2005). Legal Protection of Computer Software in Light of Intellectual Property Protection Law. Dar Jama Jadida, Alexandria.

\footnotetext{
${ }^{20}$ Article (L.112-3) of the French Intellectual Property Code defines database as " a collection of independent works, data or other materials, arranged in a systematic or methodical way, and capable of being individually assessed by electronic or any other means"

${ }^{21}$ Mohammad Ali Faris Zubi, Legal Protection of Databases ( a comparative study), master thesis, Arabic Research and Studies Institute, Cairo, 2003, p.93.
} 
Farjani, A. A. (2005). Criminal Protection against Imitation Computer Software and its Distribution, and the Violations related to Use of Internet in Various Activities. Law and Economic Journal, Faculty of Law, Zagazig University, (17).

Hawas Fathia, H. (2017). The Private Copy as a Restriction on the Financial Right of the Author. Journal of Law and Political Science, Université Abbès Laghrour Khenchela, (8).

Kanan, K. (2000). Copyright (Modern Models of Copyright and its Protection Methods) (3rd ed.). Dar Thaqafa Library, Amman.

Masri, S. S. (2015). Legal System of Information Programs as an Intellectual Property Application, (a Comparative study). Dar Nahda Arabia, Cairo.

Qourari, F. (2010). The Criminal Confrontation of Cyber-Piracy of Electronic Works by Peet to Peer. Journal of Law-Kuwait University, 1(34).

Rawi, Z. T. (2016). Un-copyrighted Works assigned for Personal Use. Retrieved from http://almerja.com/reading.php?idm=49126

Said, A. J. (2007). Towards Modern Concept of the Private Copy (A comparative study in concept of a private copy as a restriction on the exclusive rights of the author and owners of neighboring rights between digital reproduction means and measures of technological protection). Dar Nahda Arabia, Cairo.

Shalqami, S. G. (2008). Moral Right of Author of Computer Software (A study on the new Intellectual Property Protection Law No. 82 of 2002). Dar Jama Jadida, Alexandria.

Sheikh, R. A. (2005). Neighboring Rights of Copyright. Dar Jama Jadida for Publication, Alexandria.

World Intellectual Property Organization (WIPO). (1981). Glossary of copyright and neighboring rights terms.

Yasin, B. O. (2013). Ground of Permissibility in Crimes of Imitation of Literary and Artistic Works in the Algerian Legislation. Journal of Jurisprudence and Law, Algeria, (6).

Zubi, M. A. (2003). Legal Protection of Databases (a comparative study), master thesis, Arabic Research and Studies Institute, Cairo.

\section{Copyrights}

Copyright for this article is retained by the author(s), with first publication rights granted to the journal.

This is an open-access article distributed under the terms and conditions of the Creative Commons Attribution license (http://creativecommons.org/licenses/by/4.0/). 